\title{
A Case Study on Reading Aloud Using English TV News*
}

\author{
Chong, Cinthia M. \\ (Inje University)
}

\begin{abstract}
Chong, Cinthia M. (2021). A case study on reading aloud using English TV news. STEM Journal, 22(1), 1-18.
\end{abstract}

This study deals with the effectiveness of reading aloud using English TV news to increase the number of opportunities and improve self-confidence in producing English utterances for EFL learners. Reading aloud using English TV news contents was adopted to induce a certain number of English utterances, and self-voice recording via smartphones was conducted to provide an objective perspective on learners' progress during the activity. The data from the pre- and post-survey questionnaires show that the reading-aloud activity using English TV news during a single semester increased EFL learners' self-confidence in producing English utterances. Post-survey results indicate respective increases of 39 percent, 29 percent, and 20 percent in reading a text aloud, delivering a presentation, and speaking in comparison to presurvey results. Furthermore, learners with no overseas English learning experience showed significantly more positive reactions toward the reading-aloud activity than those with overseas English learning experience. The effectiveness is noticeable as it increases self-confidence to a level close to that of learners with overseas learning experience. This study provides insights into reading aloud activity using English TV news on EFL learners with no overseas learning experience and on their selfconfidence in practicing English speaking skills.

\section{INTRODUCTION}

Researchers in Korea have also studied effective ways of teaching and learning EFL and have reported some significant factors that interfere with Korean EFL learners' English-speaking competence (Chong, 2019a; Kim, 2015; Kim \& Cha, 2017; Ko, 2018; Nation, 2013; Park, 2012). Two major factors that negatively influence EFL learners, namely lack of speaking opportunity and self-confidence, are the main interests of this

\footnotetext{
* The current research is partially extracted and cited from the doctoral dissertation of Chong (2019a) at Busan University of Foreign Studies.
} 
study. In regard to the first factor, Korean EFL learners generally do not have many opportunities to interact with English speakers; this may cause them to develop anxiety and uneasiness about producing simple utterances in English, which makes them passive in English speaking. In such circumstances, it might be difficult for learners to continue practicing and improving their English-speaking competence. This context might create a vicious cycle, causing learners to lose interest and willingness to acquire skills in English. There is no doubt that EFL learners must be regularly exposed to appropriate environments and opportunities in class so that learners can apply and practice what they have learnt. Another important factor is the low self-confidence of Korean EFL learners in speaking English. Infrequent opportunities to practice the language might lead to low selfconfidence among Korean EFL learners when speaking English, even with sufficient knowledge of grammar and vocabulary.

Among the various methods and activities employed to practice English skills, reading aloud has been studied and applied as an English language teaching and learning technique. Some researchers may recognize reading aloud as an old-fashioned and dull activity, but it can be utilized as an effective technique for English teaching and learning if it is appropriately and carefully applied in class and can be regarded as one of the methods for improving learners' language skills including speaking competence and affective factors in using English (Amer, 1997; Chol \& Lewis, 2018; Gabrielatos, 2002; Gibson, 2008; Griffin, 1992). Reading aloud itself may not be easy or familiar to EFL learners and reading a text that they are seeing for the first time aloud may require further considerable focus. As Bygate (2001) states, however, giving learners the opportunity to perform the same task again can lead to improvements in performance as it enables them to retrieve crucial information from their long-term memory. Thus, this study utilizes repeated reading aloud and self-voice recordings to allow learners to experience success and check the progress made during the activities.

Furthermore, with the growing importance of English-speaking skills, overseas learning experience has emerged as a general educational practice in Korea, and a growing number of learners have been visiting English-speaking countries even before going to college. For educators in Korean EFL contexts, the concern is how to increase the number of opportunities and self-confidence in speaking English for those learners who do not have (or have rarely had) overseas English learning experience. Implementing appropriate activities in a Korean EFL class is not easy, and neither is providing all the learners with a fair amount of opportunities to speak English. According to some researchers (Cubillos \& Ilvento, 2013; Kim \& Cha, 2017), if learners have overseas learning experience, then they might have had more chances of speaking English with English speakers. That is, the learners' overseas experience may influence on their self-efficacy, anxiety, and even selfconfidence in speaking English. Thus, it seems important to closely examine different 
reactions of learners toward the reading aloud and self-voice recording activities when they have different levels of experience in English-speaking countries.

This study attempts to explore the effectiveness of reading aloud and self-voice recordings as a supplementary and effective pre-speaking method for Korean EFL learners. Then what types of texts are appropriate to be read aloud by the learners in the classroom? Gabrielatos (2002) claimed that teachers need to examine the situations in which a text is read aloud in reality, and then he suggested readings of excerpts from a news article or TV reports when implementing reading aloud activity. Adopting Gabrielatos' suggestion, English TV news contents and articles have been chosen as materials for reading aloud activities in class. To proceed with reading aloud as a pre-speaking practice method, (1) repeated reading aloud using English TV news contents has been adopted to induce a certain amount of English utterances from Korean EFL learners, and (2) repeated selfvoice recording via smartphones has been conducted to provide the learners with objective standpoints of the progress during the activity. Then the analyses between pre- and postsurvey was conducted to understand how the learners reacted to the activity using English TV news contents in class. Not much research on reading aloud using English TV news articles has been conducted in the Korean EFL context. Research investigating reading aloud using English TV news articles to increase self-confidence of Korean EFL learners has yet been rarely presented. Furthermore, it has also been imperative to broaden research on the correlations between reading aloud using English TV news articles and EFL learners' overseas English learning experience. Thus, the present study focuses on bridging this gap and provides insights into the effects of reading aloud using English TV news articles in the field of EFL teaching and learning.

\section{LITERATURE REVIEW}

\section{Effects of Reading Aloud}

Reading aloud has been widely adopted in various fields (language, psychology, and neuroscience) as a method to improve the language skills of children, foreign language learners, people with reading and phonological dyslexia, etc. Many researchers and educators in the field of English language teaching and learning have also studied and evaluated reading aloud as an effective technique to increase various language skills (Chol \& Lewis, 2018; Gabrielatos, 2002; Gibson, 2008; Griffin, 1992; Musti-Rao, Hawkins, \& Barkley, 2009). Although some critics claim that reading aloud cannot be considered as a direct communicative activity and is instead outdated and dull, it has been studied and reevaluated as a practical technique for autonomous learning by a number of researchers 
(Chol \& Lewis, 2018; Chong, 2019a; Gabrielatos, 2002; Gibson, 2008; Griffin, 1992; Huang, 2010; Kim, 2018; Musti-Rao et al., 2009; Nation, 2013; Teale, 2003; Yu, 2015). Some researchers may recognize reading aloud as an old-fashioned and dull activity, but it can be utilized as an effective technique for English teaching and learning if it is appropriately and carefully applied in class and can be regarded as one of the methods for improving learners' language skills and affective factors in using English (Amer, 1997; Chol \& Lewis, 2018; Gabrielatos, 2002; Gibson, 2008; Griffin, 1992).

Gabrielatos (2002) and Griffin (1992) discussed the correlations among reading aloud, reading, and speaking from new perspectives. They claimed pedagogical reasons and methods for utilizing reading aloud in the classroom and encouraged that this type of activity can play a major role in language learning. Gibson (2008) conducted a survey among teachers and learners of English and autonomous learners, reporting that reading aloud can be used as a technique for autonomous learning and that it plays an important role in helping many Asian learners practice pronunciation, as English sounds are different from those of their native languages. Nation (2013) also pointed out that repeatedly reading a text aloud can provide teachers with opportunities to offer feedback on pronunciation as well as allowing learners to relate the written and spoken forms of words. Furthermore, to maximize the effectiveness of reading aloud, Teale (2003) also suggested teachers to consider the amount of time, the text, and the method for reading aloud.

\section{Reading Aloud Using Multi-Media in Korean EFL Contexts}

As comprehensible language input is known to be essential at the most basic level of foreign language learning (FLL); learners in EFL contexts (in Korea, for example) have generally been provided with English inputs in class for decades. The majority of Korean EFL learners study English from their primary school years and spend more time and money studying English at private language academies. However, English is still not familiar to many Korean EFL learners; hence, educators and researchers in Korean continue searching for various methods and activities (especially using technology and multi-media) to help learners improve English skills (Chong, 2019a; Kim, 2012; Kim, 2015; Kim, 2018; Kim \& Cha, 2017; Ko, 2018; Park, 2012; Song, 2006; Yu, 2015). For instance, Kim (2018) and Yu (2015) conducted reading aloud activity, not to analyze it as a pre-speaking method but to analyze its effects mostly on reading comprehension, vocabulary, and syntactic knowledge of learners. Other researchers have examined the effects of reading aloud using multimedia in Korean EFL learning environment (Chong, 2019a; Kim, 2012; Kim, 2015; Kim, 2018) although most studies have been focused on vocabulary, reading, and listening. Among them, Kim (2012) proposed reading aloud using TV drama dialogues as an effective strategy for enhancing EFL learners' long-term 
memory and discussed reading-aloud techniques and learners' perceptions. Fewer studies have reported the correlations between reading aloud and speaking English skills (Chong, 2019b; Yu, 2015). Chong (2019b) suggested reading aloud as an adoptable translation and interpretation activity based on the data results from the self-evaluation of the EFL learners' English language skills. However, it was not easy to find studies related to the correlations between self-confidence and overseas English learning experience using TV or video materials. Thus, it was imperative to broaden research in this field and the current study may bridge this gap by providing insights into the effects of reading aloud using English TV news.

\section{METHODS}

\section{Participants}

A total of 62 university students ${ }^{1}$ participated in the study for 15 weeks, and most of them were juniors and seniors from a private university in the southern part of Korea.

TABLE 1

Details of Participants

\begin{tabular}{ccc}
\hline \hline & With No O.E. & With O.E. \\
\hline Number of participants & 42 & 20 \\
Average years of O.E. & 0 & 11 months \\
Average TOEIC score & 643 & 755 \\
\hline Note O.E = overseas experience &
\end{tabular}

In particular, 20 of them had some overseas experience (O.E.) in English-speaking countries and 42 had none. The overseas countries the participants visited as travelers, volunteers, and students were Australia, Canada, Malaysia, New Zealand, Philippines, Singapore, and USA. The overall average length of overseas stay was 11 months. To be specific, 10 participants had less than 10 months of experience, with an average period of 3 months. The remaining 10 participants had more than 10 months' experience, with an average period of 19 months. They had also obtained a Test of English for International Communication (TOEIC) score above 600 , and the overall average was 677 . To be specific, the average TOEIC score of 42 participants with no overseas experience was 643 , whereas that of those with overseas experience in English-speaking countries was 755.

\footnotetext{
${ }^{1}$ Students who wanted to improve their English skills participated in the class and their majors varied from liberal arts to science and engineering.
} 


\section{Materials and Procedures}

Teachers need to consider the amount of time and texts for reading-aloud activities to make it effective as possible. It was important to consider the quality of texts selected, so English TV news sites (and their supported news articles) were used as materials for the reading-aloud practice in the current study. As shown in Table 2, various English TV news topics (related to weather, sports, culture, health, education, technology, and economy) were selected for the learners to practice with. TV News contents related to Korea were extracted from the Korean English news channel, Arirang News (2017) retrieved from www.arirang.com, while those related to the world issues were extracted from CNN 10 (2017) retrieved from edition.cnn.com/cnn $10 .^{2}$

TABLE 2

English News Topics and Schedules

\begin{tabular}{cl}
\hline \hline \multicolumn{1}{c}{ News sites } & \multicolumn{1}{c}{ News topics } \\
\hline & Pre-survey questionnaire and background information \\
Extracted from Arirang news & $1^{\text {st }}$ topic: Weather \\
$(2017$, August-September $)$ & $2^{\text {nd }}$ topic: Culture \\
& $3^{\text {rd }}$ topic: Health \\
& $4^{\text {th }}$ topic: Science \& technology \\
\hline & $5^{\text {th }}$ topic: Weather \\
& $6^{\text {th }}$ topic: Culture \\
& $7^{\text {th }}$ topic: Health \\
& $8^{\text {th }}$ topic: Science \& technology \\
& $9^{\text {th }}$ topic: Politics \\
& $10^{\text {th }}$ topic: Terrorism \\
& Post-survey questionnaire and comments \\
\hline
\end{tabular}

The pre- and post-survey questionnaires in this study were classified into background information (such as major, school year, TOEIC score, length of overseas experience, and name of overseas countries they had visited), survey questionnaires, and comments and feedback. The effectiveness of these activities was determined based on the results of the pre and post questionnaires.

As a method of the reading-aloud practice, the learners needed a device to record their voice while reading aloud the articles; most of them used their own smartphones for this purpose. One-third of the activity groups had to perform their reading-aloud activities in front of the class while the rest of the groups had to submit their self-voice recordings via email at the end of class activity.

\footnotetext{
${ }^{2}$ More detailed information on topics is given in Appendices B and C.
} 
FIGURE 1

Procedures of the Reading Aloud Activity Using English TV News Contents

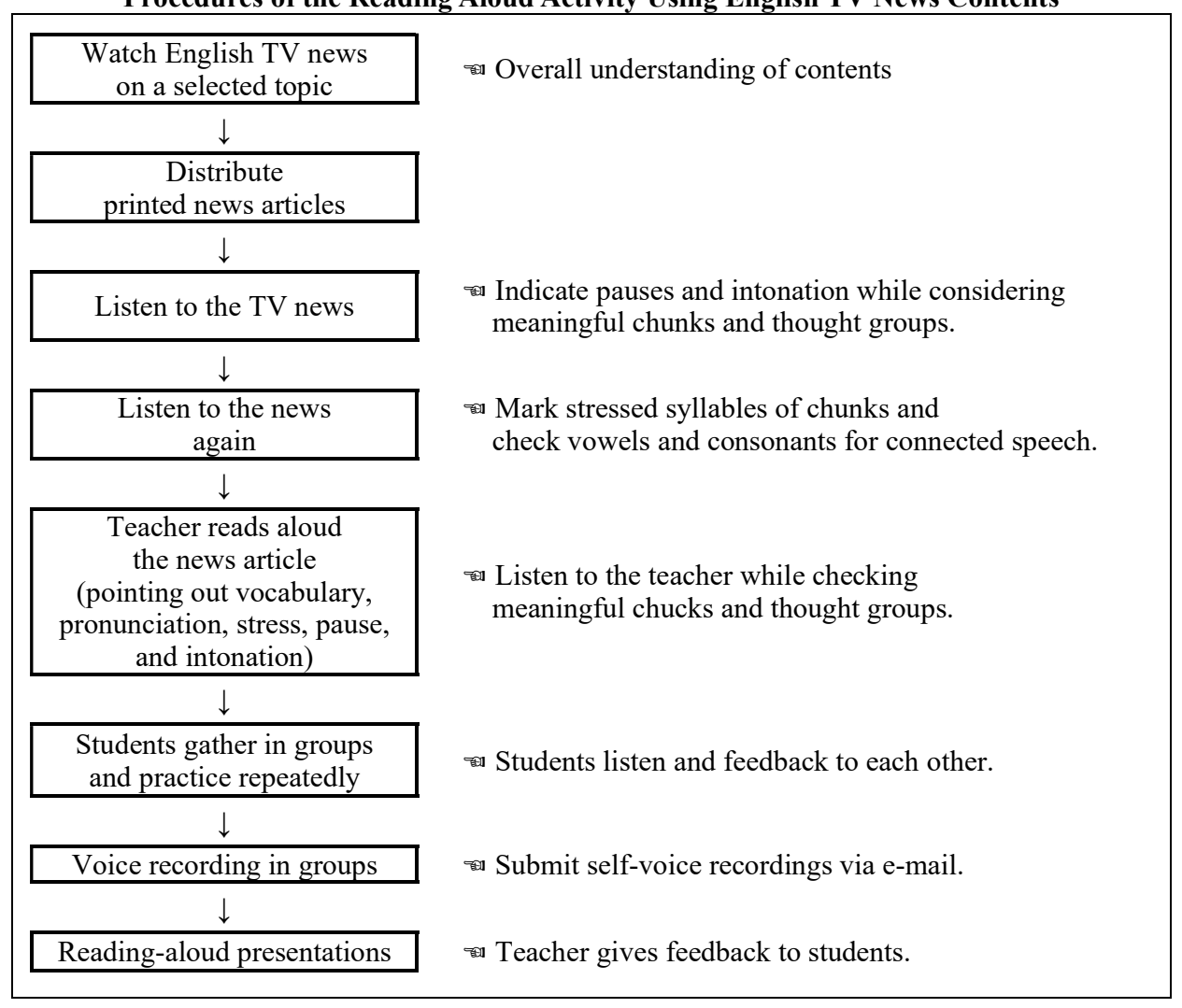

The experiment procedure shown in Figure 1 was conducted three hours a week for 15 weeks. As Bygate (1987) mentioned, it was presumed that it might be difficult for learners to read aloud from a given English news article because they are not used to the contents of texts or sentences. Thus, the learners were asked to read aloud the same contents several times at a natural speed for two purposes: (1) the learners could understand and be familiar with the super-segmental features that would help develop fluency, accuracy, and naturalness (2) the listeners could understand the content (what was being read) comfortably and with minimal effort.

After the individual practice, the learners were divided into teams of three to four people and were assigned to practice as a team for 30 to 40 minutes. During the group practice, learners had a chance to give comments and feedback to each other. Later, one-third of the teams performed the "reading aloud English TV news articles" activity in front of their listeners, while the rest submitted their voice recordings of the assigned subject. The learners had to record their voices repeatedly until they completed each assigned task. This 
process of repeated practice and self-voice recordings was included for every readingaloud activity until the learners felt comfortable with the given texts and subjects, affording both the teachers and the learners a better chance to notice errors when producing utterances.

\section{Data Analysis}

Data were gathered from survey questionnaires. Surveys were conducted twice-a presurvey in the beginning and as a post-survey at the end of the research-to investigate the reactions of EFL learners regarding the reading-aloud activity using English TV news. The survey questionnaires used the format of a typical five-point Likert scale ( $1=$ strongly disagree, $2=$ disagree, $3=$ neither agree nor disagree, $4=$ agree, $5=$ strongly agree). To explore learners' reactions to the reading-aloud activity using English TV news followed by self-voice recordings via smartphones, mean scores, standard deviations, $t$-values, and $p$-values were analyzed. SPSS 25 was used for statistical analyses.

\section{RESULTS AND DISCUSSION}

To examine the learners' reactions regarding the reading-aloud practice using English TV news followed by self-voice recordings via smartphones, pre- and post-survey questionnaires were compared and analyzed using an SPSS $t$-test. The results were specifically analyzed further based on the overseas experience of learners (no overseas experience, less than a year of overseas experience, and more than a year of overseas experience) to investigate their distinctive reactions. In fact, through comments and feedback at the end of the semester, some learners with overseas learning experience expressed that they were afraid of making noticeable mistakes when performing reading aloud in front of listeners. Thus, it was considered that learners might react differently to the reading-aloud activity based on their length of overseas experience in Englishspeaking countries.

TABLE 3

Overall Statistics on the Learners' Self-Confidence in English Utterances

\begin{tabular}{ccccccc}
\hline \hline & \multicolumn{7}{c}{ Pre-survey } & \multicolumn{2}{c}{ Post-survey } & \multirow{2}{*}{$t$-value } & $p$-value \\
& $M$ & $S D$ & $M$ & $S D$ & & \\
\hline Reading a text aloud & 3.08 & 0.907 & 3.58 & 0.934 & -3.655 & $.001^{* *}$ \\
Delivering a presentation & 2.54 & 0.831 & 3.05 & 0.991 & -3.568 & $.001^{* *}$ \\
Speaking & 2.83 & 0.821 & 3.12 & 0.910 & -2.367 & $.021^{*}$ \\
\hline
\end{tabular}


From pre- and post-surveys, the overall statistics for the survey questions related to selfconfidence in English utterances ("I have confidence in reading a text aloud," "delivering a presentation," and "speaking") were found to be significantly meaningful with $p$-values of .001 both in "reading a text aloud" and "delivering a presentation" and .021 in "speaking," as can be seen in Table 3. Overall changes in the reaction of leaners between pre- and post-survey questions on self-confidence in English utterances are shown in Figure 2 below.

\section{FIGURE 2}

Overall Changes in the Learners' Reaction to Self-Confidence in English Utterances

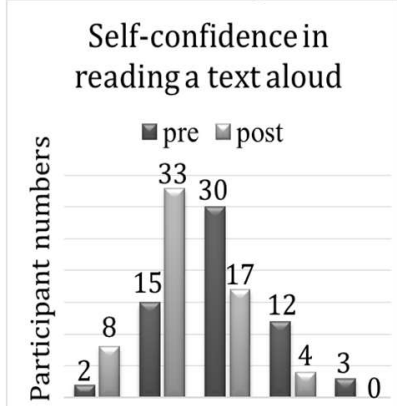

SA A N DA SDA
Self-confidence in delivering a presentation

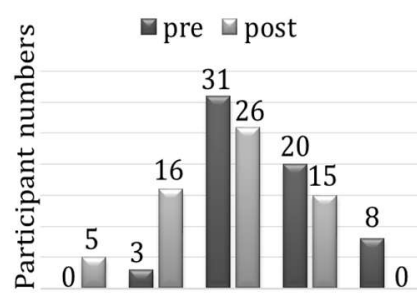

SA A N DA SDA
Self-confidence in speaking

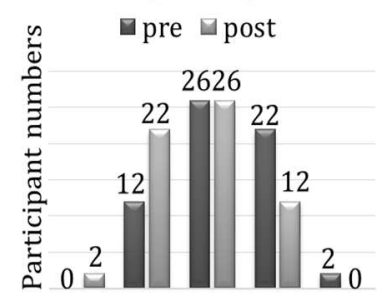

SA A N DA SDA

Note. $\mathrm{SA}=$ strongly agree, $\mathrm{A}=$ agree, $\mathrm{N}=$ neither agree nor disagree, $\mathrm{DA}=$ disagree, $\mathrm{SDA}=$ strongly disagree

While 17 learners (27\%) in "reading a text aloud," 3 (5\%) in "delivering a presentation," and $12(19 \%)$ in "speaking" answered the question positively in the pre-survey, $41(66 \%)$ in "reading a text aloud," 21 (34\%) in "delivering a presentation," and $24(39 \%)$ in "speaking" answered it positively in the post-survey. It is worth noticing increases of 39, 29 , and $20 \%$ in "reading a text aloud," "delivering a presentation," and speaking, respectively.

Repeated activities of reading aloud using English news media followed by self-voice recording continuously provided learners with opportunities to produce English utterances. Such repetitive English utterance activities have helped the learners familiarize themselves with speaking English. The repetitive opportunity and familiarity in producing English utterances have induced a higher self-confidence among the learners; thus, it is possible to infer that the reading-aloud practice using English news media had a positive and effective impact on the learners in terms of increasing their self-confidence in producing English utterances.

Let us then look at different reactions to the self-confidence in English utterances after repeated reading-aloud activities based on the length of learners' overseas learning experience. 
TABLE 4

Statistics on the Learners' Self-Confidence Based on their Overseas Experience (O.E.)

\begin{tabular}{|c|c|c|c|c|c|c|}
\hline \multirow{2}{*}{ Reading a text aloud } & \multicolumn{2}{|c|}{ Pre-survey } & \multicolumn{2}{|c|}{ Post-survey } & \multirow{2}{*}{$t$-value } & \multirow{2}{*}{$p$-value } \\
\hline & $M$ & $S D$ & $M$ & $S D$ & & \\
\hline No O.E. & 2.93 & 0.915 & 3.49 & 0.895 & -3.602 & $.001 * *$ \\
\hline$<1$ year of O.E. & 3.42 & 0.900 & 3.67 & 1.155 & -0.583 & .571 \\
\hline$>1$ year of O.E. & 3.38 & 0.744 & 4.00 & 0.756 & -1.667 & .140 \\
\hline \multirow{2}{*}{ Delivering a presentation } & \multicolumn{2}{|c|}{ Pre-survey } & \multicolumn{2}{|c|}{ Post-survey } & \multirow{2}{*}{$t$-value } & \multirow{2}{*}{$p$-value } \\
\hline & $M$ & $S D$ & $M$ & $S D$ & & \\
\hline No O.E. & 2.38 & 0.860 & 2.93 & 0.939 & -3.330 & $.002 * *$ \\
\hline$<1$ year of O.E. & 2.83 & 0.577 & 3.00 & 1.128 & -0.411 & .689 \\
\hline$>1$ year of O.E. & 3.00 & 0.756 & 3.75 & 0.886 & -2.393 & $.048^{*}$ \\
\hline \multirow{2}{*}{ Speaking } & \multicolumn{2}{|c|}{ Pre-survey } & \multicolumn{2}{|c|}{ Post-survey } & \multirow{2}{*}{$t$-value } & \multirow{2}{*}{$p$-value } \\
\hline & $M$ & $S D$ & $M$ & $S D$ & & \\
\hline No O.E. & 2.69 & 0.821 & 3.04 & 0.852 & -2.377 & $.022 *$ \\
\hline$<1$ year of O.E. & 2.92 & 0.669 & 3.00 & 0.953 & -0.266 & .795 \\
\hline$>1$ year of O.E. & 3.50 & 0.756 & 3.75 & 1.035 & -0.798 & .451 \\
\hline
\end{tabular}

Note. ${ }^{*} p<.05,{ }^{*} p<.01$
Note. No O.E. $=$ with no overseas experience, $<1$ year of O.E. $=$ with less than one year of overseas experience

$>1$ year of O.E. = with more than one year of overseas experience

Data for the survey questions ("I have confidence in reading a text aloud," "delivering a presentation," and "speaking") were categorized and analyzed by the length of overseas learning experiences of the learners. However, the results presented a slightly different view from that of Table 3. Considering the data in Table 4, only the $p$-values of learners with no overseas experience were significant concerning self-confidence in "reading a text aloud" $(p=.001)$, "delivering a presentation" $(p=.002)$, and "speaking" $(p=.022)$. The improvements of mean scores on self-confidence for the learners with no overseas experience are noticeable as they increase to a level close to that of learners who had overseas experience.

As seen in Figure 3, while only 7 learners out of 42 (17\%) in "reading a text aloud," 0 $(0 \%)$ in "delivering a presentation," and $5(12 \%)$ in "speaking" answered the question positively in the pre-survey, $24(57 \%)$ in "reading a text aloud," $11(26 \%)$ in "delivering a presentation," and $13(31 \%)$ in "speaking" answered it positively in the post-survey. It is worth noticing increases of 40,26 , and $19 \%$ in "reading a text aloud," "delivering a presentation," and "speaking," respectively.

This repetitive reading aloud using English TV news followed by self-voice recordings via smartphones in class has been a more useful and effective practice method, especially for learners with no overseas experience, in terms of increasing self-confidence in producing English utterances. Most of the learners with overseas learning experience had 
higher levels of self-confidence in English utterances in the pre-survey compared to those with no overseas experience. Thus, the improvement in figures related to self-confidence in these English utterances seemed less noticeable.

FIGURE 3

Changes in Reactions of the Learners With No Overseas Experience

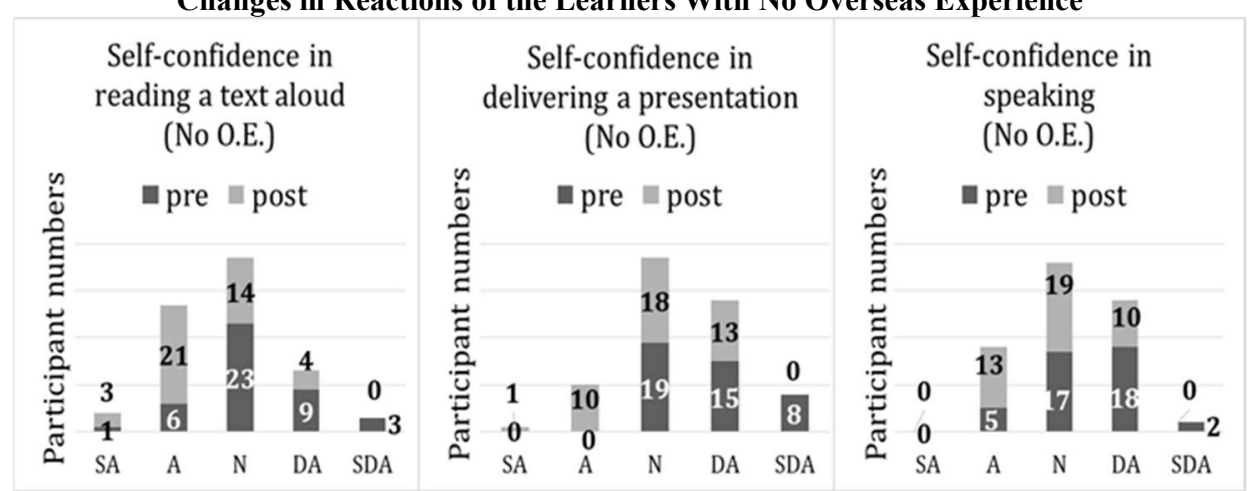

Note. $\mathrm{SA}=$ strongly agree, $\mathrm{A}=$ agree, $\mathrm{N}=$ neither agree nor disagree, $\mathrm{DA}=$ disagree, $\mathrm{SDA}=$ strongly disagree

Although the reading-aloud activity using English TV news seemed useful for learners with more than one year of overseas experience, as it improved their self-confidence in "delivering a presentation" ( $p=.048)$, performing reading aloud English TV news articles in front of the other listeners might have influenced the rise in tension among these learners. Kitano (2001) claimed that the anxiety level of learners with overseas experience was higher than that of those who have no experience. He also stated that the learners who had overseas experience might be under pressure that they have to speak the target language nearly as native speakers do. Similar to the claim of Kitano (2001), the comments and feedback of some learners at the end of the study showed the similar reactions in this study. Having more experience of learning English overseas might pressure them to have higher English skills and might lead to higher expectations, namely that they must perform well when reading texts aloud in front of others in this study. It can further be assumed that such tension had a partially positive effect on these learners' motivation to further practice using English utterance skills. It is also possible to imply that reading aloud English TV news articles in front of listeners after repeated practice might have given these learners the chance to utilize their English presentation skills.

Let us now look at the next survey question "I am willing to keep producing English utterances to improve my communication skills" to find out any difference in reactions among the learners after reading-aloud activities through English TV news. 
TABLE 5

Statistics on Willingness to Produce English Utterances

\begin{tabular}{|c|c|c|c|c|c|c|}
\hline & \multicolumn{2}{|c|}{ Pre-survey } & \multicolumn{2}{|c|}{ Post-survey } & \multirow{2}{*}{$t$-value } & \multirow{2}{*}{$p$-value } \\
\hline & $M$ & $S D$ & $M$ & $S D$ & & \\
\hline Overall & 2.42 & 0.900 & 3.78 & 0.760 & -9.054 & $.001 * *$ \\
\hline No O.E. & 2.38 & 0.960 & 3.71 & 0.695 & -7.303 & $.001 * *$ \\
\hline$<1$ year of O.E. & 2.42 & 0.669 & 4.00 & 0.953 & -3.978 & $.002 * *$ \\
\hline$>1$ year of O.E. & 2.63 & 0.916 & 3.88 & 0.835 & -3.416 & $.011 *$ \\
\hline
\end{tabular}

Note. No O.E. $=$ with no overseas experience,$<1$ year of O.E. $=$ with less than one year of overseas experience,

$>1$ year of O.E. = with more than one year of overseas experience

The overall $p$-value $(p<.001)$ in Table 5 indicates that the reading-aloud practice using English TV news followed by self-voice recordings via smartphones also had a positive influence on most of the learners' willingness to produce English utterances. Unlike selfconfidence in English utterances, all the $p$-values (whether learners had overseas experience or not) showed that the learners were willing to keep producing English utterances after the reading-aloud activity using English TV news. In other words, it can be said that the reading-aloud practice using English TV news helped the learners realize the importance of producing English utterances to improve their English communication skills.

FIGURE 4

Overall Changes in Learners' Reactions to Willingness for Producing English Utterances

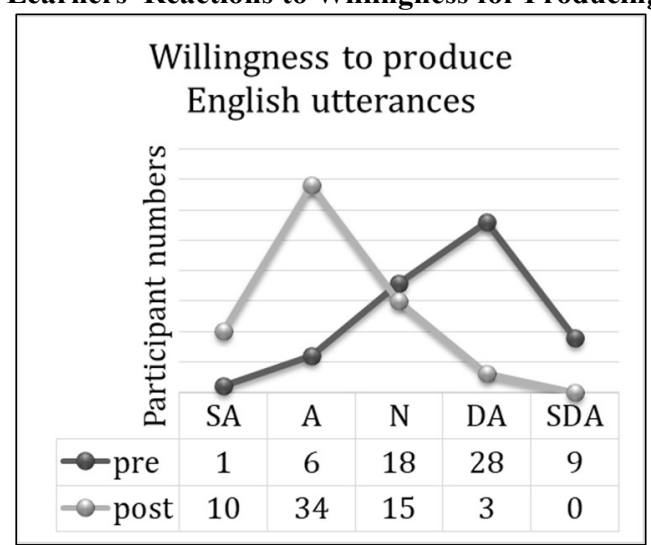

Note. $\mathrm{SA}=$ strongly agree, $\mathrm{A}=$ agree, $\mathrm{N}=$ neither agree nor disagree, $\mathrm{DA}=$ disagree, $\mathrm{SDA}=$ strongly disagree

As seen in Figure 4, the number of learners willing to keep producing English utterances increased from $7(11 \%)$ in the pre-survey to $44(71 \%)$ in the post-survey, recording an increase of $60 \%$. The number of learners who responded "disagree/strongly disagree" decreased from $37(60 \%)$ to $3(5 \%)$, indicating that the reading-aloud practice using 
English TV news also reminded those who did not recognize the relation between English utterances and speaking that they could practice their speaking skills by producing English utterances.

In the Korean EFL context, where the majority of EFL learners do not have enough interactions with English speakers in their daily environment or with their English teachers in class, the reading-aloud activity using English TV news followed by self-voice recordings via smartphones seemed to be useful in helping learners produce more English utterances and to improve their self-confidence in using English. Especially learners who rarely have a chance for overseas learning experience had more positive and significant reactions to the activity of reading aloud using English TV news than those with overseas learning experience. Although there were some differences in the reactions according to the learners' overseas learning experience, the data results show that the activity of reading aloud using English TV news followed by self-voice recordings via smartphones can be utilized as a supplementary and effective practice method for EFL learners to increase the number of opportunities and self-confidence in producing English utterances.

\section{CONCLUSION}

For EFL learners who rarely visit English-speaking countries or interact with English speakers in a daily environment, the infrequent opportunities to use the language may cause them to develop anxiety and uneasiness about producing a simple utterance in English; this might lead to a lack of self-confidence in EFL learners when speaking English. Therefore, to help learners maintain a high level of self-confidence and interest in English learning, it is necessary to provide them with opportunities to practice and regular experiences of accomplishment in class.

To find an efficient supplementary method for practicing English utterances in the Korean EFL context, this study conducted reading aloud using English TV news followed by self-voice recordings via smartphones to allow learners to produce English utterances in class and gain an objective standpoint of their progress during the activity. Furthermore, analyses were carried out on the reactions of learners depending on whether they had overseas learning experience in English-speaking countries. Based on the data outcomes, it was understood that reading aloud using English TV news might provide EFL learners (especially for those who rarely have a chance for overseas English learning experience) with exposure to an environment where they can increase the amount of English utterances and their self-confidence in using English. In other words, reading aloud using English TV news followed by self-voice recordings via smartphones can be recommended as a supplementary and effective practice method to provide opportunities and increase 
learners' self-confidence in using English-speaking skills in the EFL context.

As is mentioned earlier, the majority of Korean EFL learners do not have sufficient interactions with English speakers in daily environments and with their English teachers in class. In such contexts, the suggested repeated reading aloud using English news and repeated self-voice recording activities in this research may be useful 1) to guide EFL learners and raise their awareness of pre-speaking methods, 2) to make EFL learners participate in pre-speaking activities, and 3) to help EFL learners to increase the amount of English utterances they make, which may lead to improvements in their speaking competence. However, the comprehension of a written text is important in terms of practicing reading aloud as a pre-speaking activity. It may be hard for some EFL learners to read texts aloud if they do not understand the meaning of the contents. Therefore, the language skills of EFL learners should be considered with discretion especially for learners with a novice level of English.

\section{REFERENCES}

Amer, A. A. (1997). The effect of the teacher's reading aloud on the reading comprehension of EFL students. ELT Journal, 51(1), 43-47. doi:10.1093/elt $/ 51.1 .43$

Arirang News. (2017, August-September). Retrieved from http://www.arirang.com Bygate, M. (1987). Speaking. Oxford: Oxford University Press.

Bygate, M. (2001). Effects of task repetition on the structure and control of oral language. In M. Bygate, P. Skehan, \& M. Swain (Eds.), Researching pedagogic tasks: Second language learning, teaching, and testing (pp. 23-49). Harlow, UK: Longman.

Chol, R., \& Lewis, M. (2018). From reading aloud to peer interaction: The effect of oral reading on EFL proficiency. The Journal of Asia TEFL, 15(3), 787-796. doi:10.18823/asiatefl.2018.15.3.14.787

Chong, C. M. (2019a). A comparative study of college students' reaction and attitude from English utterance output activities in Korean EFL contexts (Unpublished doctoral dissertation). Busan University of Foreign Studies, Busan.

Chong, C. M. (2019b). Exploring effective translation activities at college level with reference to reading aloud: A case study. The Journal of Interpretation \& Translation Education, 17(3), 131-151. doi:10.23903/kaited.2019.17.3.007

CNN 10 News. (2017, September-November). Retrieved from http://edition.cnn.com/cnn10 
Cubillos, J., \& Ilvento, T. (2013). The impact of study abroad on students' self-efficacy perceptions. Foreign Language Annuals, 45(4), 494-511. doi:org/10.1111/j.19449720.2013.12002.x

Gabrielatos, C. (2002). Reading loud and clear: Reading aloud in ELT. ERIC: ED477572.

Gibson, S. (2008). Reading aloud: A useful learning tool. ELT Journal, 52(1), 29-36. doi:10.1093/elt/ccm075

Griffin, S. (1992). Reading aloud: An educator comments. TESOL Quarterly, 26(4), 784787. doi: $10.2307 / 3586890$

Huang, L. (2010). Reading aloud in the foreign language teaching. Asian Social Science, 6(4), 148-150. doi:10.5539/ass.v6n4p148

Kim, H. (2015). Multimedia application in the college classroom for autonomous language learning. STEM Journal, 16(2), 157-173. doi:10.16875/stem.2015.16.2.157

Kim, H., \& Cha, K. (2017). Effects of experience abroad and language proficiency on selfefficacy beliefs in learning language. Psychological Reports, 120(4), 670-694. doi:10.1177/0033294117697088

Kim, N. (2018). Effects of reading aloud tasks through a mobile phone on EFL vocabulary and reading comprehension skills. Multimedia-Assisted Language Learning, 21(1), 57-76. doi:10.15702/mall.2018.21.1.57

Kim, S. (2012). Learning English through reading aloud using the Mentalist: A case study of four Korean university students. STEM Journal, 13(2), 39-59. doi:10.16875/stem.2012.13.2.39

Kitano, K. (2001). Anxiety in the college Japanese language classroom. The Modern Language Journal, 85(4), 549-566. doi:org/10.1111/0026-7902.00125

Ko, H. (2018). Evaluation on self-directed learning activities by a low level of Korean EFL learners. English Language Teaching, 30(1), 19-46. doi:10.17936/pkelt.2018.30.1.002

Musti-Rao, S., Hawkins, R., \& Barkley, E. (2009). Effects of repeated readings on the oral reading fluency of urban fourth-grade students: Implications for practice. Preventing School Failure, 54(1), 12-23. doi:10.3200/PSFL.54.1.12-23

Nation, P. (2013). What should every ESL teacher know. Seoul: Compass.

Park, G. (2012). Investigation into the constructs of the FLCAS. English Teaching, 67(2), 207-220. doi:10.15858/engtea.67.2.201207.207

Song, J. (2006). Student-centered writing and speaking practice on the internet. English Language Teaching, 18(2), 179-202.

Teale, W. H. (2003). Reading aloud to young children as a classroom instructional activity: Insight from research and practice. In A. van Kleeck, S. A. Stahl, \& E. B. Bauer (Eds.), On reading books to children: Parents and teachers (pp. 114-139). Mahwah, NJ: Erlbaum. 
$\mathrm{Yu}, \mathrm{K}$. (2015). Is reading aloud beneficial for Korean college-level English learners. Studies in English Language \& Literature, 41(1), 283-312. doi:10.21559/aellk.2015.41.1.014

\section{APPENDIX A}

Survey Questions

\begin{tabular}{|l|l|l|l|l|l|}
\hline \multicolumn{1}{|c|}{ Survey questions } & 5 & 4 & 3 & 2 & 1 \\
\hline \hline I have confidence in reading a text aloud in English. & & & & & \\
\hline I have confidence in delivering a presentation in English. & & & & & \\
\hline I have confidence in speaking English. & & & & \\
\hline $\begin{array}{l}\text { I am willing to keep practicing (producing utterances) English to improve } \\
\text { my communication skills. }\end{array}$ & & & & & \\
\hline
\end{tabular}

Note. (5) strongly agree, (4) agree, (3) neither agree nor disagree, (2) disagree, and (1) strongly disagree.

\section{APPENDIX B}

Extracted News Topics Used for Reading Aloud

\begin{tabular}{|c|c|c|}
\hline $\begin{array}{c}\text { Arirang } \\
\text { news }\end{array}$ & & $\begin{array}{l}\text { Weather (2017, August 30) } \\
\text { http://www.arirang.com/News/News_View.asp?nseq=208095 } \\
\text { Culture (2017, August 18) } \\
\text { http://www.arirang.com/News/News_View.asp?nseq=207644 } \\
\text { Health (2017, September 11) } \\
\text { http://www.arirang.com/News/News_View.asp?nseq=208519 } \\
\text { Science \& technology (2017, September 20) } \\
\text { http://www.arirang.com/News/News View.asp?nseq=208872 }\end{array}$ \\
\hline $\begin{array}{c}\text { CNN } 10 \\
\text { news }\end{array}$ & & $\begin{array}{l}\text { Weather (2017, September 20) } \\
\text { http://transcripts.cnn.com/TRANSCRIPTS/1709/20/sn.01.html } \\
\text { Culture (2017, October 15) } \\
\text { http://edition.cnn.com/2017/10/15/cnn10/ten-content-mon/index.html } \\
\text { Health }(2017, \text { October 25) } \\
\text { http://edition.cnn.com/2017/10/24/cnn10/ten-content-weds/index.html } \\
\text { Science \& technology }(2017, \text { September 15) } \\
\text { http://edition.cnn.com/2017/09/14/cnn10/ten-content-fri/index.html } \\
\text { Politics }(2017, \text { September 20) } \\
\text { http://edition.cnn.com/2017/09/28/cnn10/ten-content-fri/index.html } \\
\text { Terrorism }(2017, \text { November 2) } \\
\text { http://edition.cnn.com/2017/11/01/cnn10/ten-content-thurs/index.html }\end{array}$ \\
\hline
\end{tabular}

\section{APPENDIX C}

Examples of English TV News Contents Used for Reading Aloud

\section{Extracted from Arirang news}

Health: R U OK DAY (2017, September 11)

http://www.arirang.com/News/News_View.asp?nseq=208519 
ANCHOR: Sunday marked World Suicide Prevention Day. And to support those struggling with depression and other problems, a special event was held in Seoul. It aims to make a difference in Korea and hopefully reduce what is one of the highest suicide rates in the world.

Our Park Hee-jun went to check it out and filed this report.

PARK HEE-JUN, ARIRANG NEWS CORRESPONDENT: September 10th is World Suicide Prevention Day and for the first time in Korea, the Stella Foundation hosted a "R U OK" day at Korea National Sport University in southern Seoul.

R U OK is a suicide prevention charity based in Australia that aims to inspire people to connect with others, while helping those struggling to cope with the pressures of life.

"Just think that it's a very important issue to address and everyone should be aware of what to watch for with their family members and with their friends so that they can prevent suicide."

"R U OK DAY KOREA" offered various happiness booths where visitors could enjoy sports, take a rest, and even make new friends.

Key speakers, including an Olympic Gold medalist fencer and famous broadcaster also offered advice based on their own experiences.

"As an athlete, I pushed myself to think positively. It really helped me to overcome my problems."

"Travelling has a healing effect. It gives you courage and the chance to look at life in a whole new way."

Because researchers say a lack of sleep is one of the main causes of suicide, the Stella Foundation set up a booth where visitors can rest comfortably and even take a nap under the sun. And as well as getting enough sleep, it's important to make sure you exercise regularly as this also helps prevent depression and other psychiatric disorders.

A portion of the event was also set aside for visitors to try out different kinds of sports including taekwondo, badminton, and more.

South Korea has the highest suicide rate among OECD nations. 15-thousand people end their lives each year meaning a person commits suicide in Korea every 38 minutes.

By coming to a country with serious issues with suicide, the Stella Foundation aims to make a difference, by providing opportunities for people to encourage each other and find meaning in their lives.

So, take time to look after your own mental wellbeing and keep an eye on the people around you because a simple conversation can always make a difference.

Extracted from CNN 10 news

Health: About an Outbreak of Food Poisoning (2017, October 25)

http:/edition.cnn.com/2017/10/24/cnn10/ten-content-weds/index.html

CARL AZUZ (voice-over): Ten-second trivia:

Which of these pathogens is an example of bacteria? Salmonella, influenza, rabies, or smallpox? Salmonella, the only bacteria of these options, is capable of causing severe food poisoning in people.

CARL AZUZ: There's been an outbreak of salmonella and clostridium perfringens, another bacterial infection, in the U.S. state of Louisiana. At least 37 people have been hospitalized, one person has died from sickness possibly related to this outbreak.

In all, around 150 cases of gastrointestinal illness had been reported so far, but health officials expect more to be on the way.

The reason: suspected contamination in jambalaya that was served to hundreds of people at a fundraiser last week. Jambalaya is a Louisiana dish made with chicken, sausages, vegetables, rice, sometimes, seafood. Investigators don`t know yet which ingredient or ingredients were contaminated, but both pathogens can be found in raw meat and poultry.

ELIZABETH COHEN, CNN SENIOR MEDICAL CORRESPONDENT: Salmonella is a bacteria that makes people sick. You can find it in beef, poultry, eggs, fruits, vegetables and processed foods. Salmonella can contaminate foods in the field or sometimes in the processing plant. Sometimes, salmonella can get into food in your own kitchen. For example, if you 're cutting up chicken on one cutting board and you don`t clean it properly and then you cut off 
vegetables that you re not going to cook, that's called cross-contamination.

Salmonella can also live on the bodies of animals like reptiles or chickens. So, if you touch them and you don 't wash your hands, you could get yourself sick. People usually get sick about 12 to

72 hours after eating contaminated food and symptoms include fever, diarrhea, and abdominal cramps.

Each year in the United States, 1.2 million people get sick from salmonella and 450 people die.

To keep yourself from getting sick from salmonella, cook foods thoroughly.

Don`t eat raw eggs. Don`t drink unpasteurized milk.

Applicable levels: secondary, college, adult education

Keywords: English TV news, smartphone, reading aloud, self-confidence, overseas experience

Chong, Cinthia M.

Assistant Professor

College of Liberal Arts

Inje University

Inje-ro 197, C433, Gimhae, Gyeongsangnam-do, 50834, Korea

E-mail: cmhchong@inje.ac.kr

Received: December 29, 2020

Revised version: February 13, 2021

Accepted: February 22, 2021 